Food and Chemical Toxicology Volume 44, Issue 5 , May 2006, Pages 678-688

doi:10.1016/j.fct.2005.09.007

Copyright (c) 2005 Elsevier Ltd All rights reserved.

\title{
Significance of ammonium compounds on nicotine exposure to cigarette smokers
}

\author{
E.W. Willems*, B. Rambali, W. Vleeming, A. Opperhuizen and J.G.C. van \\ Amsterdam
}

Laboratory for Toxicology, Pathology and Genetics, National Institute for Public Health and the Environment (RIVM), P.O. Box 1, 3720 BA Bilthoven, The Netherlands

* Corresponding author. Tel.: +31 (0)30 274 4506; fax: +31 (0)30 2744446 .

\begin{abstract}
The tobacco industry publicly contends that ammonia compounds are solely used as tobacco additive for purposes of tobacco flavoring, process conditioning and reduction of its subjective harshness and irritation. However, neither objective scientific reports, nor the contents of a large number of internal tobacco company documents support this contention.
\end{abstract}

The present review focuses on the hypothesis that addition of ammonium compounds to tobacco enhances global tobacco use due to smoke alkalization and enhanced free-nicotine nicotine exposure. Obviously, ammonia enhances the alkalinity of tobacco smoke. Consequently, the equilibrium shifts from non-volatile nicotine salts to the volatile free base that is more readily absorbed from the airways. The observed change in the kinetics of nicotine (i.e., shorter $t_{1 / 2}$ and higher $c_{\max }$ ) after ammoniation is, however, predominantly due to the higher concentration of nicotine in the smoke, rather than to an increase in the absorption rate of free-base nicotine in the respiratory tract.

Although several findings support the hypothesis, additional studies are required and suggested to provide a proper, objective and independent scientific judgment about the effect of tobacco ammoniation on nicotine bioavailability. Scientific and public awareness of the effects of tobacco-specific ammonia compounds may stimulate global control, legislation and restriction of their use in cigarette manufacture.

Abbreviations: BAT, British American Tobacco company; B\&W, Brown \& Williamson; RJR, RJ Reynolds Tobacco Company; WHO, World Health Organization; FDA, US Food and Drug Administration; FTC, Federal Trade Commission; USDHHS, US Department of Health and Human Services; CDC, Centers for Disease Control and Prevention; TFI, Tobacco Free Initiative; NTE, Nicotine Transfer Efficiency; MS, Mainstream; SS, Sidestream; ID, Internal document from tobacco industry; MAC, Occupational Maximal Acceptable Concentration; STEL, Short Term Exposure Level; PEL, Permissible Exposure Limit; ETS, Environmental Tobacco Smoke 


\section{Introduction}

Tobacco smoking, the main cause of lung cancer (Boyle et al., 2004, Hurt and Robertson, 1998, Kessler, 1994b and Muggli et al., 2004), takes an enormous toll on public health and is the world's leading cause of preventable deaths (Schroeder, 2004 and WHO-TFI, 2004). Yearly, five million people die world-wide due to tobacco use (CDC, 1988, Ezzati and Lopez, 2003 and WHO-TFI, 2004), a number that has been estimated by the World Health Organization (WHO) to be doubled in about 15 years.

The scientific literature and the recent availability of previously confidential internal documents from various tobacco companies have demonstrated that the incidence of tobacco use is manipulated by adding several compounds (Bates et al., 1999, Hurt and Robertson, 1998, Muggli et al., 2004 and Schroeder, 2004). The world-wide use of tobacco additives has initiated discussions and legislation measures on tobacco-related additives and their putative adverse health effects (Cummings et al., 2002).

The present review focuses on the hypothesis that addition of ammonium compounds to tobacco enhances global tobacco use. Though the tobacco companies shun to properly inform the public on this subject on their web-sites, ammonia improves nicotine's bioavailability by increasing the fraction of free-base nicotine in whole tobacco. The underlying mechanisms of these effects are outlined and discussed to understand the rationale of their use in tobacco product manufacture. In addition, the exposure to and the adverse health effects of ammonia as tobacco additive are briefly reviewed.

Public peer-reviewed data have provided the basis of the review on this topic. Information retrieved from internet and, particularly, the internal tobacco industry documents has been contemplated with caution and skepticism (Cummings et al., 2002, Diethelm et al., 2004, Drope and Chapman, 2001, Hurt and Robertson, 1998, Kessler, 1994b, Kessler et al., 1996, Kessler and Myers, 2001, Muggli et al., 2004 and Wilner and Feingold, 2000). Internal documents have therefore been specified and referred to as ID's, when cited.

\section{Exposure of tobacco smokers to ammonia}

Highly water soluble ammonia $\left(\mathrm{NH}_{3}\right)$ is a weak base with a p $K_{\mathrm{a}}$-value of 9.4 (Hunt et al., 2002). Ammonia has a very pungent odor and is used as household cleaning agent and fertilizer.

Ammonia is also a natural component of tobacco. Its content varies from $0.1 \%$ in flue-cured tobacco to $0.5 \%$ in dark tobacco, which results in ammonia amounts in smoke of 51 and $153 \mu \mathrm{g}$, respectively (Sloan and Morie, 1974). In addition, ammonia and ammonium salts are added as ingredient, giving a final ammonia content of 0.1-6 mg per gram tobacco (cf. Table 1). Other processes that increase the level of ammonia in tobacco (smoke) are: (i) pyrolysis of proteins and other organic nitrogen compounds in the tobacco blend; (ii) reduction of nitrate during the smoking process; (iii) residual ammonia in the blend; and (iv) decomposition of ammonia-containing additives (e.g., ammonia compounds) (Lauterbach, 2000). 
Table 1.

Background information on ammonia

\begin{tabular}{|c|c|c|}
\hline Item & $\begin{array}{l}\text { Level } \\
(\mathrm{ppm})^{\mathrm{a}}\end{array}$ & Remark \\
\hline \multicolumn{3}{|l|}{ Exposure routes: } \\
\hline Air & $0.01-0.005$ & $\begin{array}{l}\text { Exposure levels are sensitive to location and activity; } \\
\text { major fluctuations observed }\end{array}$ \\
\hline Soil & $1-5$ & \\
\hline Water & $<6$ & \\
\hline Ingestion from food/drinks & - & $18 \mathrm{mg}$ per day \\
\hline $\begin{array}{l}\text { Formed from nitrogenous matter } \\
\text { in food/drinks }\end{array}$ & - & $\begin{array}{l}4.2 \mathrm{~g} \text { of ammonia is endogenously formed in the } \\
\text { digestive tract per day }\end{array}$ \\
\hline Normal human blood level & $400-700$ & $400-700 \mathrm{mg} / \mathrm{L}$ (based on $7 \mathrm{~L}$ of blood) \\
\hline $\begin{array}{l}\text { Tobacco-derived intake ( } 20 \\
\text { cigarettes per day) }\end{array}$ & - & $\begin{array}{l}35 \mathrm{mg} \text {, assuming max. ammonia-level of } 700 \mathrm{ppm} ; 10 \\
\text { puffs of } 35 \mathrm{ml} \text { per cigarette }\end{array}$ \\
\hline Averaged urban level & 0.03 & $\begin{array}{l}25 \mu \mathrm{g} / \mathrm{m}^{3} ; \text { per day about } 0.5 \mathrm{mg} \text { of } \mathrm{NH}_{3} \text { is inhaled } \\
\left(20 \mathrm{~m}^{3} \text { air breathed per day }\right)\end{array}$ \\
\hline Exhaled air level & $0.13-2.86$ & $\begin{array}{l}0.1-2.2 \mathrm{mg} / \mathrm{m}^{3} \text { in healthy volunteers; } \leqslant 80 \% \text { of } \mathrm{NH}_{3} \text { in } \\
\text { food/drinks is exhaled }\end{array}$ \\
\hline Alveolar breath level & $0.18-0.55$ & $0.14-0.42 \mathrm{mg} / \mathrm{m}^{3} ;$ during fasting \\
\hline Lower odor detection & 45 & $35 \mathrm{mg} / \mathrm{m}^{3}$ \\
\hline MAC-value (occupational) & $23-52$ & $18-40 \mathrm{mg} / \mathrm{m}^{3}$; in The Netherlands: $18 \mathrm{mg} / \mathrm{m}^{3}(26 \mathrm{ppm})$ \\
\hline STEL $^{\mathrm{b}}$ & 35 & $27 \mathrm{mg} / \mathrm{m}^{3}$ \\
\hline $\mathrm{PEL}^{\mathrm{b}}$ & 25 & $18 \mathrm{mg} / \mathrm{m}^{3}$ \\
\hline Indigenous amount in tobacco & - & $0.01-0.6 \%(w / w)$ of tobacco \\
\hline $\begin{array}{l}\text { Amount used in cigarette } \\
\text { manufacture }\end{array}$ & & $\begin{array}{l}0.02-1.0 \%(\mathrm{w} / \mathrm{w}) ; \text { total ammonia content of one } \\
\text { cigarette is } 0.2-10 \mathrm{mg} / \mathrm{g}\end{array}$ \\
\hline Mainstream smoke level & $19-742$ & $7-200 \mu \mathrm{g}$ per gram of tobacco smoked \\
\hline Sidestream smoke level & - & $\begin{array}{l}320-450 \mu \mathrm{g} \text { per gram of tobacco smoked; } 40-170 \text { fold } \\
\text { higher level than in MS smoke }\end{array}$ \\
\hline
\end{tabular}

Data from references: (Smith et al., 2001, Steele et al., 1994, BAT, 1982, Johnson, 1989, WHO, 1986, WHO, 2004, Hoffmann and Hoffmann, 1998, Huang et al., 2003, Sloan and Morie, 1974, Sloan and Morie, 1976, Djordjevic et al., 2000, Carmines, 2002, Counts et al., 2004, Djordjevic, 2004, Spanel et al., 1998, Baker, 1999, Neurath, 1969, Anonymous, 1979, Covington and Burling, 1993, Covington and Burling, 1994, Sudholt, 1996, Hoffmann and Hoffmann, 1997, Hoffmann and Hoffmann, 2004, Bases, 1984, Baker et al., 2004b, Davis and Nielsen, 1999, Stabbert et al., 2003 and USDHHS, 1990).

a $1 \mathrm{ppm} \mathrm{NH}$ corresponds to $700 \mu \mathrm{g} \mathrm{NH} \mathrm{NH}_{3}$ per $\mathrm{m}^{3}$.

b STEL: Short-Term Exposure Limit; PEL: Permissible Exposure Limit.

Upon smoking tobacco, about $90 \%$ of the ammonia in inhaled smoke is retained in the nasal mucosa and the lining fluid of the upper airways. Studies in volunteers have shown that prolonged exposure to $500 \mathrm{ppm}$ ammonia results in a much lower (about 30\%) retention of the ammonia; the rest being excreted by expiration (USDHHS, 1990). This limited capacity to absorb ammonia has been confirmed by others (Anonymous, 1979, Silverman et al., 1949 and WHO, 1986).

As depicted in Table 1 , some $18 \mathrm{mg}$ of ammonia is ingested daily via food and drinks, and about $4 \mathrm{~g}$ of ammonia is daily produced in the body from from nitrogenous matter in the nutrition, including urea (WHO, 1986 and USDHHS, 1990) [ID (Heck, 1993)].

Ammonia levels in cigarette mainstream smoke (MS smoke) vary from 19 to $742 \mathrm{ppm}$ (cf. Table 1), implicating that the upper level in MS smoke greatly exceeds the average urban air level $(0.03 \mathrm{ppm})$ and the occupational maximal 
acceptable concentration (MAC-value) of $26 \mathrm{ppm}$. Assuming continuous inhalation of the maximal amount of ammonia in MS smoke (700 ppm), the daily dose of a pack-a-day smoker is $35 \mathrm{mg}$ (10 puffs of $35 \mathrm{ml}$ per cigarette); a considerable lower dose of $0.8 \mathrm{mg}$ per day was calculated by Sloan and Morie (Sloan and Morie, 1974). Ammonia levels in second-hand smoke (ETS) are some 40-170 fold higher than in MS smoke, and breathing $20 \mathrm{~m}^{3}$ of this atmosphere $(10 \mu \mathrm{g}$ of ammonia per $\mathrm{m}^{3}$ ) gives an intake of $0.2 \mathrm{mg}$ of ammonia per day.

In non-smoking healthy subjects, blood levels of ammonia ranged from 400 to $700 \mathrm{mg} / \mathrm{L}$ (Anonymous, 1979, USDHHS, 1990 and WHO, 1986). Ammonia is excreted via exhaled air, sweat or urine [ID (Steele et al., 1994)]. Urinary ammonia excretion rate varies from 0.3 to $1.0 \mathrm{mg} /$ day [ID (Covington and Burling, 1994)].

\section{Human toxicity of ammonia}

Ammonia levels, at the upper levels during smoking, cause throat irritation $(400 \mathrm{ppm})$, increase the breathing rate $(500 \mathrm{ppm})$, and induce cough (1700 ppm) (Silverman et al., 1949). Human inhalation studies with ammonia exposure periods varying from $6 \mathrm{~h}$ /day during 6 weeks to $3 \mathrm{~h} /$ day for 2-3 years showed that ammonia at a level of $29 \mathrm{ppm}$ produces mild irritations in the eyes, nose and throat (Anonymous, 1979, Brautbar et al., 2003, Issley et al., 2004, USDHHS, 1990 and WHO, 1986). Epidemiological studies have shown that exposure to 50200 ppm ammonia (with durations varying from acute to 90 days) can elicit chronic obstructive lung disease, chronic latent lung function damage, pulmonary fibrosis, bronchitis/bronchiolitis (Brautbar et al., 2003) and decrease the minute volume associated with a higher mean respiratory frequency (Anonymous, 1979 and CDC, 1974). The MAC-value and the 15-min STEL (short term exposure level) for ammonia are 26 and 35 ppm, respectively.

\subsection{Impact of nicotine}

Tobacco is a complex chemical mixture of several thousand potentially toxic constituents and more than 5000 in its smoke (Baker et al., 2004a, Counts et al., 2004, Hoffmann and Hoffmann, 2004 and Leffingwell, 1999). The nicotine in tobacco is mainly present as the pharmacologically more active [S]-enantiomer that elicits tobacco dependence (Henningfield et al., 2004, Henningfield et al., 1993, Hurt and Robertson, 1998, Soc. Neurosc., 2004 and USDHHS, 1988). Tobacco smoking is further characterized by a transient constriction of the upper airways, a brief increase in blood pressure, respiration rate and heart rate, and various other physiological effects (e.g., relaxation in stress situations (Karan and Benowitz, 2000 and Soc. Neurosc., 2004); see ID (Creighton, 1987)). These effects (referred to as "impact" or "kick") are attained via neuronal cholinergic activation and the release of neurotransmitters, like norepinephrine and dopamine (Henningfield and Benowitz, 2004, McGehee et al., 1995, Karan and Benowitz, 2000 and Pich et al., 1997).

\subsection{Absorption and elimination of nicotine}

Cigarettes represent very efficient nicotine 'delivery devices' that enable much faster and completer nicotine absorption [ID (Backhurst, 1966)], as compared to tobacco gum and nicotine spays. Inhalation of the tobacco smoke of one cigarette (0.9-1.1 $\mathrm{g}$ of whole tobacco containing $6-11 \mathrm{mg}$ of nicotine) rapidly delivers $1-$ $3 \mathrm{mg}$ of nicotine to the airways of the smoker (Henningfield, 1995, Djordjevic et al., 2000, Benowitz and Jacob, 1994b, Benowitz and Henningfield, 1994a, Hoffmann and Hoffmann, 1998, Hoffmann and Hoffmann, 2004 and Van Andel et 
al., 2003) [see ID (Backhurst, 1966)]. Within a few seconds about $90 \%$ of the nicotine is absorbed in the upper and lower airways (Armitage and Turner, 1970, Henningfield et al., 2004, Henningfield and Benowitz, 2004, Henningfield et al., 1993, Henningfield, 1995 and Johnson, 1977), the rest is swallowed and timedelayed absorbed via the intestinal route [ID (Reininghaus, 1994)]. At 4 and 6 min following the smoking of one cigarette peak arterial (some $45 \mathrm{ng} / \mathrm{mL}$ ) and venous (some $25 \mathrm{ng} / \mathrm{mL}$ ) blood nicotine levels are attained (Domino et al., 2004, Guthrie et al., 2004, Henningfield, 1995, Lee et al., 2004, Lunell et al., 2000, Malson et al., 2003 and USDHHS, 1988).

The typical pack-per-day smoker absorbs about 20-40 mg nicotine per day (Benowitz et al., 1983, Benowitz and Henningfield, 1994a, Djordjevic et al., 2000 and Djordjevic, 2004). Usually, early on the day the nicotine blood level of these heavy smokers reaches a plateau (steady-state) level of about $30 \mathrm{ng} / \mathrm{mL}$, which levels-off overnight to a baseline value of some $5 \mathrm{ng} / \mathrm{mL}$ (USDHHS, 1988). A similar kinetic profile is seen upon smoking cigarettes that contain low $(0.4 \mathrm{mg})$ or high nicotine $(2.5 \mathrm{mg})$, although the respective plateau levels are different (about 10 and $40 \mathrm{mg} / \mathrm{mL}$, respectively) (USDHHS, 1988).

MS tobacco smoke contains both volatile free-base nicotine and particle bound nicotine. Fresh MS smoke of US blended, non-filter cigarettes contains about 5 billion spherical droplets with a particle size of 0.1-1.0 $\mu \mathrm{m}$ (Hoffmann and Hoffmann, 1998). Deposition measurements during cigarette smoking indicate that $50-95 \%$ of these particles is deposited mainly in the upper airways: $11-23 \%$ is deposited in the nasal, oral, pharyngeal, and laryngeal regions; $45-81 \%$ in the tracheo-broncheal region, and around $26-35 \%$ in the pulmonary region. Iwase et al. (1991) showed that deeply inhaled nicotine-containing particles are also deposited in the lower respiratory tract (Iwase et al., 1991); [ID (Reininghaus, 1994)].

Pankow (2001) proposed four different mechanisms by which compounds in tobacco smoke aerosols attain the respiratory tissues (cf. Fig. 3): (i) direct gas deposition; (ii) evaporative gas deposition; (iii) particle deposition with evaporation; and (iv) particle deposition with diffusion. Nicotine, being present in both the particulate fraction and the gas phase, may be deposited in the respiratory tract via each of these four ways (Pankow, 2001). The way of nicotine deposition is of major importance for the absorption rate of nicotine. If deposited via direct gas deposition, free-base nicotine directly enters the lining fluid of the respiratory tract, where it is rapidly absorbed. Quite in contrast is the slow absorption via the particle deposition way, because nicotine has to diffuse from the particulate matter to the lining fluid of the respiratory tract before it is absorbed.

The current literature suggests that, depending on $\mathrm{pH}$, free-base nicotine levels in the particulate fraction of commercial cigarette smoke can be as much as $40 \%$, which is deposited in and absorbed via the airways (Pankow, 2001). The uptake of nicotine via the buccal epithelium of the mouth is complex and the amounts of nicotine absorbed here remain to be elucidated [ID (Reininghaus, 1994)].

Nicotine is mainly and rapidly ( $t_{1 / 2}$ of $9 \mathrm{~min}$ ) metabolized to cotinine, but the metabolic pathways of nicotine will not be discussed here since these do not seem to be affected by ammonia compounds. Only $5-10 \%$ of nicotine is cleared renally with a $t_{1 / 2}$ elimination value of $2-3 \mathrm{~h}$, depending on urinary $\mathrm{pH}$ and flow rate (Henningfield, 1995, Karan and Benowitz, 2000, Soc. Neurosc., 2004 and USDHHS, 1988). Only minor quantities of nicotine are excreted via saliva (USDHHS, 1988). 


\subsection{Publicly claimed effects of ammonia by tobacco industry}

Annually, about five million kilos of ammonia are used in the manufacture of US cigarettes, an amount that corresponds to $10 \mathrm{mg}$ of ammonia per cigarette produced [ID (Johnson, 1989)]. In addition to ammonia, various ammonium salts like $\mathrm{NH}_{4} \mathrm{HCO}_{3}$ and $\left(\mathrm{NH}_{4}\right)_{2} \mathrm{HPO}_{4}$, and urea, are commonly used as tobacco additives in the cigarette manufacture (usually max. $5 \% \mathrm{w} / \mathrm{w}$ ) serving as a source of ammonia.

Table 2 summarizes the results of previously confidential documents of the tobacco industry. The tobacco industry publicly contends that ammonia compounds are only used as tobacco additive to flavor tobacco, to reduce its subjective harshness and irritation, and to 'condition' the tobacco process (CDC, 1974, Dixon and Lambing, 2000, Hurt and Robertson, 1998, Leffingwell, 1999 and Muggli et al., 2004); ID [(BAT, 1982)]. Indeed, part of the internal documents have described rather vague applications like (i) combustion modifier, (ii) paper improvement, (iii) tobacco/smoke ammonia content enhancer, (iv) flavor/body/taste enhancer, ( $v$ ) irritation reducer; and (vi) reducer of toxic constituents in smoke [ID (B\&W, 1991)]. Other internal documents, however, have clearly described (cf. Table 2 ) that ammonia and ammonium compounds "modifies the tobacco/smoke nicotine content", i.e., ammonia is added to tobacco to decrease the acidity of tobacco smoke with the aim to increase the concentration of nicotine in smoke [ID (Creighton, 1987)].

Table 2.

Use of ammonium compounds in cigarette manufacture

\begin{tabular}{|l|l|}
\hline $\begin{array}{l}\text { Particular } \\
\text { property/effect }\end{array}$ & Description \\
\hline Combustion modifier & $\begin{array}{l}\text { Expansion of tobacco, ash conditioner, burn retardants, } \\
\text { sustainers/accelerators (smolder retardant) }\end{array}$ \\
\hline $\begin{array}{l}\text { Sheet physical quality } \\
\text { improver }\end{array}$ & Releasing natural binders, pectins and softening fibers \\
\hline $\begin{array}{l}\text { Tobacco nicotine content } \\
\text { modifier }\end{array}$ & Reducers (e.g., tobacco expansion) \\
\hline & Enhancers (tobacco to smoke transfer) \\
\hline $\begin{array}{l}\text { Smoke nicotine content } \\
\text { modifier }\end{array}$ & Reducers (filter acidification) \\
\hline \hline $\begin{array}{l}\text { Tobacco/smoke } \mathrm{NH}_{3} \\
\text { enhancer }\end{array}$ & Enhancers (distribution to free fraction in smoke; impact booster) \\
\hline Flavor/body/taste enhancer & $\begin{array}{l}\text { Smoothing, cooling effect to the taste; several patents have been } \\
\text { described }\end{array}$ \\
\hline Irritation reducer & Scavenging of irritant components or by tobacco expansion \\
\hline pH regulator & Whole tobacco and smoke \\
\hline
\end{tabular}

a Other ammonium compounds used as tobacco additive that affect (decrease or increase) $\mathrm{pH}$ : $\mathrm{NH}_{4}$-associated organic acids, $\mathrm{NH}_{4} \mathrm{Ac}, \mathrm{NH}_{4} \mathrm{Cl}, \mathrm{NH}_{4} \mathrm{OH}, \mathrm{NH}_{3}$, $\left(\mathrm{NH}_{4}\right)_{2} \mathrm{HPO}_{3}$ (DAP), urea, $\mathrm{NH}_{4} \mathrm{HCO}_{3}, \mathrm{NH}_{4} \mathrm{OH},\left(\mathrm{NH}_{4}\right)_{2} \mathrm{SO}_{4}, \mathrm{NH}_{4} \mathrm{Cl}$.

The research to ammonia as enhancer of the nicotine dose has been extensive and goes back to 1966, when an internal document from the tobacco company BAT [ID (Backhurst, 1966)] described that the reaction of a smoker to the strength of tobacco was more related to the amount of free-base nicotine in the smoke, than to the total nicotine content. This study further showed that following extraction of several tobaccos with chloroform, the amount of nicotine in 
the chloroform phase, being the nicotine free-base fraction, depended on the $\mathrm{pH}$ of the aqueous phase (ranging from 5 to 8) [ID (Backhurst, 1966)].

Much later in 1991, the American tobacco company's handbook of leaf blending and product development [ID (B\&W, 1991)], as well as the FDA (Kessler, 1994b) coined the use of ammonia-compounds by the tobacco industry as "impact booster", i.e., increasing the impact and 'satisfaction' reported by smokers; see also Bates et al., 1999, Hebert, 2004, Henningfield and Benowitz, 2004, Hurt and Robertson, 1998, Kessler, 1994a and Kessler et al., 1996. In the same period, the US Department of Health and Human Services (USDHHS) and the FDA acknowledged that the psychoactive and reinforcing effects of nicotine increase with the speed of its absorption (Henningfield and Benowitz, 2004). Although the alkalinity of tobacco smoke was accepted as a major factor in nicotine absorption, other internal documents [cited in (EPA-FTC, 1978)] argued that smoke contact time with mucus membranes, $\mathrm{pH}$ of the membrane and body fluids, depth and degree of inhalation, degree of habitat of the smoker, nicotine and moisture content and puff frequency are highly relevant for nicotine absorption, as well. Other objective scientific reports (Peedin, 1999, Boyle et al., 2004 and Davis and Nielsen, 1999) have confirmed the $\mathrm{pH}$-regulatory function of ammonium compounds (in whole tobacco and its smoke).

Finally, some internal documents of tobacco companies have claimed that treatment of whole tobacco with ammonium-compounds (e.g., di-ammonium phosphate; DAP) modified the nicotine content of tobacco [US Patent No. 4,215,706; ID's (B\&W, 1990a, B\&W, 1991, BAT, 1988, Larson, 1980, Lorillard, 1984 and B\&W, 1990b)]. This modification has been described as "nicotine scavenging" or "root technology". The mechanisms by which ammonia increases the bioavailability of nicotine are outlined below.

\subsection{Ammonia and nicotine in mainstream smoke}

The $\mathrm{p} K_{1,2}$-values of nicotine, being 8.02 (pyrrolidine) and 3.04 (pyridine nitrogen) at $25^{\circ} \mathrm{C}$, respectively (Weast, 1970 ) implicate that nicotine is protonated (i.e., is a non-volatile salt) at $\mathrm{pH}$ values below five (Seeman et al., 2004, Henningfield et al., 2004 and Domino, 1999). At higher pH values (>5) nicotine is gradually deprotonated to its volatile free-base form (cf. Fig. 1). MS smoke consists of a vapor phase and a particulate ('tar') fraction. Whereas the vapor phase contains only nicotine in its volatile non-protonated (i.e., free-base) form (Dixon and Lambing, 2000, Hurt and Robertson, 1998, Pankow et al., 1997, Pankow, 2001, Rodgman, 2000 and Seeman et al., 1999), the particulate fraction contains both protonated and non-protonated nicotine in a ratio that depends on the $\mathrm{pH}$-value of this fraction (the diprotonated nicotine is of no importance in smoking). 
<smiles>CN1CCC[C@H]1c1cccnc1</smiles>

(R)-Nicotine<smiles>CN1CCC[C@H]1c1cccnc1</smiles>

(S)-Nicotine<smiles>C[NH+]1CCC[C@H]1c1cccnc1</smiles>

Diprotonated<smiles>C[NH+]1CCC[C@H]1c1cccnc1</smiles>

Monoprotonated<smiles>CN1CCC[C@H]1c1cccnc1</smiles>

Nonprotonated (Free-Base)

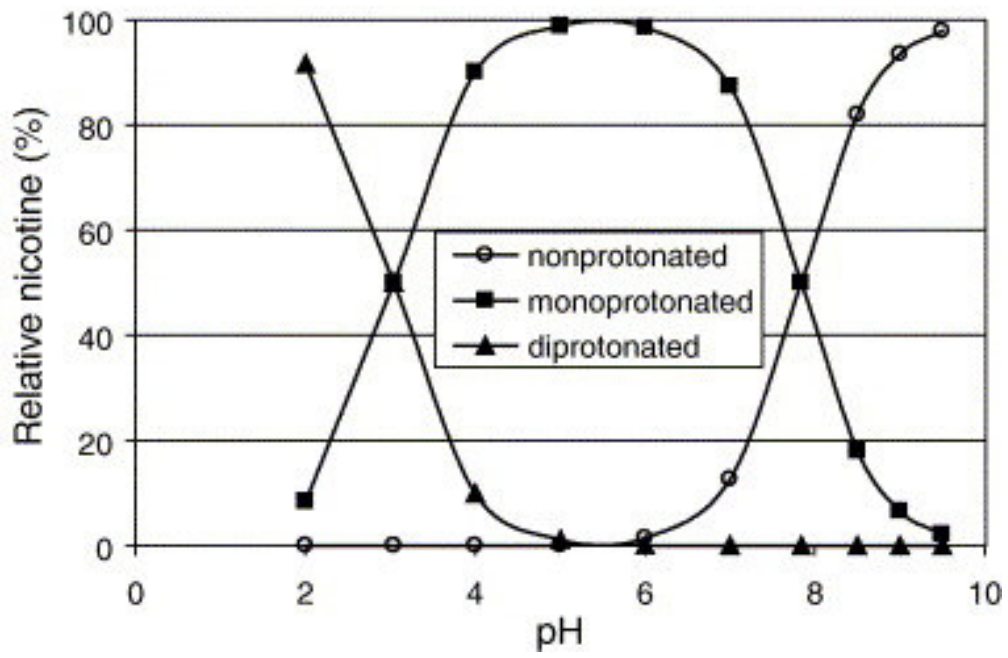

Fig. 1. Chemical structures of nicotine's forms and their percentages as function of $\mathrm{pH}$, ranging from 2 to 9.5. Modified from Hoffmann and Hoffmann (1997).

As outlined in the previous paragraph on absorption and elimination of nicotine, the rate of nicotine absorption depends on the way of nicotine deposition (Pankow, 2001). Studies to the effect of ammonia or ammonium compounds on the deposition of tobacco smoke derived nicotine-containing particles have, however, not been described.

By definition, only aqueous solutions (and not gasses) have a $\mathrm{pH}$-value. To properly compare pH values of smoke, Pankow (2001) introduced the parameter 'effective $\mathrm{pH}$ of the tobacco smoke particulate matter phase for nicotine $\left(\mathrm{pH}_{\text {eff }}\right)^{\text {', }}$ which also considers the free-base nicotine fraction in MS smoke (i.e., drawn and inhaled by smoker). The MS smoke $\mathrm{pH}_{\text {eff }}$ values (hereinafter referred to as $\mathrm{pH}$ ) of eleven different cigarette brands ranged from 5.8 to 7.8 (Pankow, 2001). As can be referred from Fig. 1, tobacco smoke at a pH of 5.8 contains mainly nonvolatile mono-protonated nicotine, while the free-base nicotine fraction gradually increases at higher tobacco smoke pH: at pH 7.8 about $30 \%$ of total nicotine in smoke is present as free-base (Bates et al., 1999, Burch et al., 1993, Hoffmann and Hoffmann, 1997, Lauterbach, 2000, Pankow, 2001, Seeman et al., 1999 and Seeman et al., 2004). An internal BAT document [ID (BAT, 1970)] described several ammoniation studies (e.g., $\mathrm{NH}_{3}, \mathrm{NH}_{4} \mathrm{OH}$; max. $4 \% \mathrm{w} / \mathrm{w}$ ) and reported 
increased values for nicotine delivery (30-45\%), "extractable nicotine" (27$63 \%)$, smoke $\mathrm{pH}(30-31 \%)$, and ammonia levels in smoke (59-105 times) as compared to control cigarettes. The effect of ammonia on smoke $\mathrm{pH}$ is illustrated by Fig. 2, showing that among different tobacco products the level of total and free ammonia in smoke proved to be positively associated with the $\mathrm{pH}$ of the smoke (from 5.2 to 7.4) (Sloan and Morie, 1976). Though the uptake of nicotine in the mouth and lungs is complex and not well understood [ID (Reininghaus, 1994)], it seems evident that alkalization of the smoke by ammonia promotes nicotine absorption.
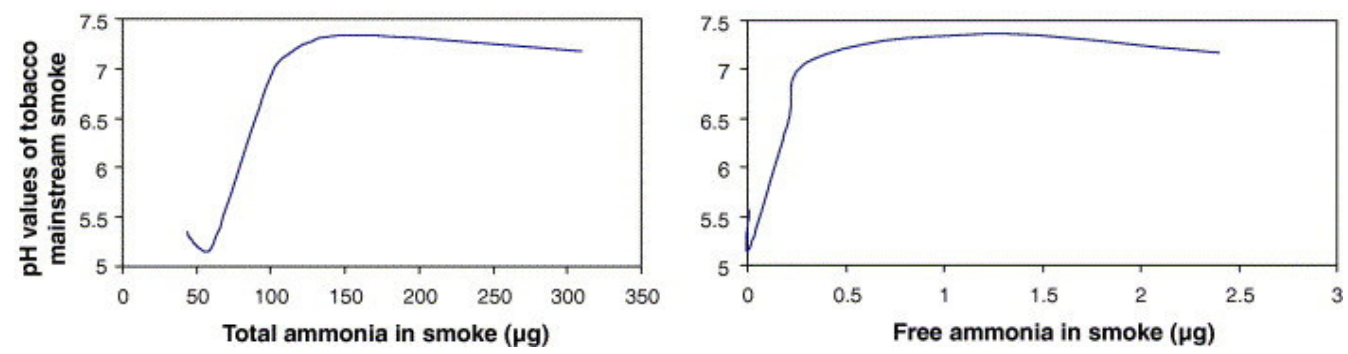

Fig. 2. Effect of total ammonia smoke levels on measured $\mathrm{pH}$ value of tobacco mainstream smoke. Modified from Sloan and Morie (1976).

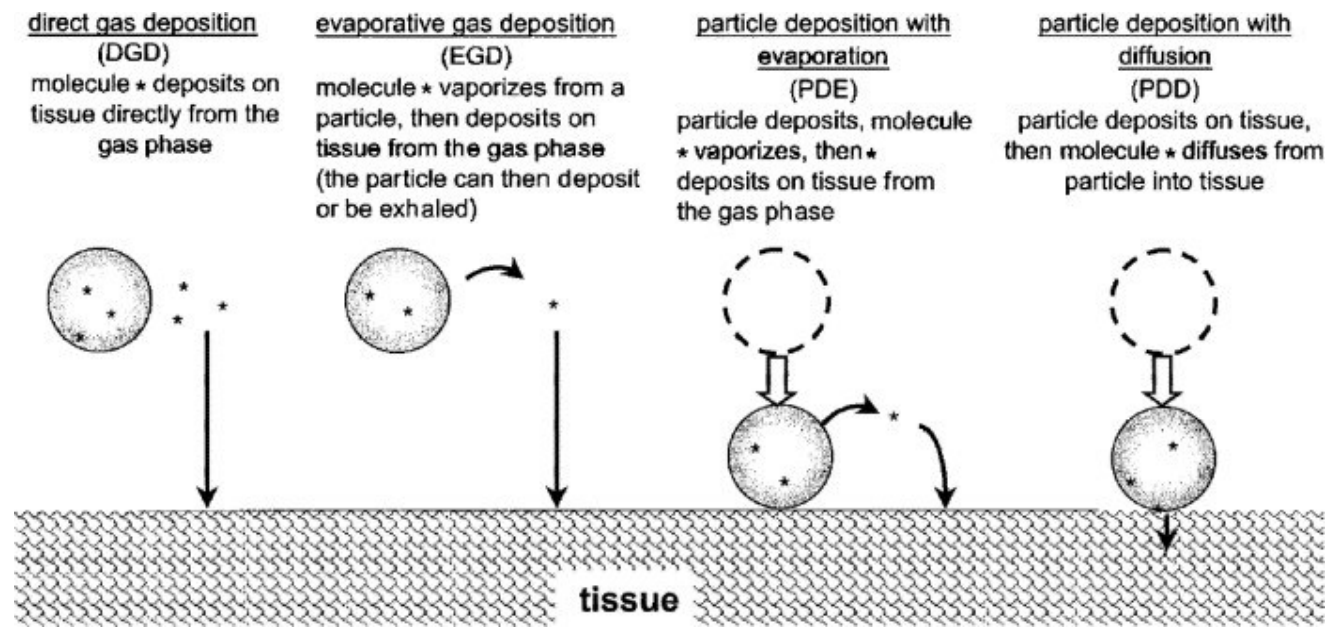

Fig. 3. Four mechanisms by which molecules (each of which is represented as an asterisk $(*))$ in a tobacco smoke aerosol can come into molecular contact with tissues in the airways; adapted from Pankow (2001) with permission.

Sidestream smoke (SS smoke; secondary smoke during smolder) of a cigarette contains some 3-fold higher total nicotine levels than MS smoke i.e., $0.8-2.3 \mathrm{mg}$ per cigarette (Bates et al., 1999, Burch et al., 1993, Hoffmann and Hoffmann, 1997, Lauterbach, 2000, Pankow, 2001, Seeman et al., 1999 and Seeman et al., 2004), presumably because free-base nicotine easily evaporates near the hot tip of the cigarette. Apparently, much of the free ammonia evaporates from the tobacco, due to the generation of heat during smoking, and explains why SS smoke contains some 40-170 fold higher concentrations of ammonia than MS smoke (cf. Table 1) (Bates et al., 1999, Burch et al., 1993, Hoffmann and Hoffmann, 1997, Lauterbach, 2000, Pankow, 2001, Seeman et al., 1999 and Seeman et al., 2004). The $\mathrm{pH}$-value of SS smoke averages that of MS smoke ( $\mathrm{pH}$ of 6.7-7.5), so that up to $30 \%$ of total nicotine in SS smoke is present in its free- 
Food and Chemical Toxicology Volume 44, Issue 5 , May 2006, Pages 678-688

base form. Obviously, the addition of ammonia to tobacco also increases the (free-base) nicotine level in SS smoke (cf. Fig. 1).

\section{Effect on nicotine transfer and distribution}

"Nicotine transfer efficiency" (NTE) reflects the ratio between the amount of nicotine in the smoke near the heat source (tip of a lit cigarette) and the amount present in the respective unburned tobacco (Seeman et al., 1999). Burley tobaccos $(\mathrm{pH} 7.6)$ have higher NTE values $(20.6 \%)$ than flue-cured tobaccos $(\mathrm{pH}$ $5.6 ; 18.7 \%)$ and Oriental tobaccos (pH 5.1; 18.7\%) [ID (BAT, 1995)]. Another study showed that addition of ammonia from $0.1 \%$ to $0.5 \%$ increased smoke ammonia levels and enhanced NTE from $13 \%$ to $18 \%$ [ID (Johnson, 1989)]. Finally, ammonia treatment $(0.54 \% \mathrm{w} / \mathrm{w})$ increased the $\mathrm{pH}$ value of tobacco $(+16 \%)$, the amount of nicotine in filter $(+45 \%)$, and nicotine in tobacco smoke $(+26 \%)$ [ID (Johnson, 1977)].

\section{Effect on oral absorption of nicotine}

Transport of ammonia across membranes is $\mathrm{pH}$-dependent: free ammonia $\left(\mathrm{NH}_{3}\right)$ freely diffuses across membranes, whereas ammonium salts $\left(\mathrm{NH}_{4}^{+}\right)$are confined to cellular compartments [ID (Steele et al., 1994)]. The absorption rate of nicotine depends therefore on the form (free-base, protonated) in which nicotine is presented to buccal-pulmonary epithelial tissue. Similarly, the absorption rate of nicotine and the amount of nicotine absorbed is smoke pH-dependent.

Several studies suggest that nicotine absorption in the oral cavity is increased by alkali, including ammonia (cf. Table 2). The promoting effect of alkali on the oral nicotine absorption has been demonstrated in cats exposed to alkalinized nicotine aerosols and solutions, and in humans with alkalinized mouths treated with nicotine sublingual tablets (Molander and Lunell, 2001, Armitage and Turner, 1970 and Burch et al., 1993) and [ID (Reininghaus, 1994)]. An early tobacco industry document describes that about four times more nicotine is absorbed by the smoker from basic smoke as compared to acid smoke [cited in ID (EPA-FTC, 1978)]. The study with sublingual nicotine tablets revealed a slightly higher absorption rate of nicotine, i.e., a significant shorter $t_{\max }$ value $(P<0.05)$ in alkalinized versus acidified mouths (Molander and Lunell, 2001). The difference between the total amount of nicotine absorbed (area under the curve; AUC) from these mouths was, however, not statistically significant $(P>0.05)$. The often cited study of Armitage and Turner (1970) clearly demonstrated in anaesthetized cats the pH-dependency of nicotine's oral absorption and bioavailability (shorter $t_{\max }$ and higher $c_{\max }$ at higher $\mathrm{pH}$ ). These data have been confirmed by another human study (Burch et al., 1993), showing increased plasma nicotine levels (8, 12 and $18 \mathrm{ng} / \mathrm{mL}$ ) after inhalation of nicotine aerosols with $\mathrm{pH}$ values of 5.6, 7.5 and 11 , respectively.

Volunteer studies showed that nicotine retention within the mouth (smoke was not inhaled) from control cigarettes was 20-26\% [ID (Backhurst, 1966)] and $46 \%$ (Armitage et al., 2004), respectively. Treatment of cigarettes with $4 \% \mathrm{w} / \mathrm{w}$ DAP and urea significantly increased nicotine retention in the mouth during the mouth-retention to $64 \%$ and $53 \%$, respectively (Armitage et al., 2004), but DAP or urea treatment did not increase the venous blood level of nicotine. However, when the mouth-hold condition was followed by inhalation $(500 \mathrm{ml})$ DAP and urea did not increase the amount retained (and blood nicotine level) as compared to control cigarettes. In fact, control cigarettes (no ammonia added) gave already complete retention (99.1\%) of nicotine (Armitage et al., 2004). It is remarkable that the treatment with urea or DAP failed to increase the blood nicotine level 
(Armitage et al., 2004). Unfortunately, Armitage and co-workers have not reported whether smokers perceived increased mouth retention of nicotine by ammoniation in terms of cigarette strength (i.e., increased "impact", "kick").

\section{Effect on pulmonary absorption of nicotine}

The airway epithelium has a pH of about 7.6 (CDC, 1988, Hunt et al., 2000 and Kostikas et al., 2002), and a high buffer capacity of $7 \mathrm{mval} / \mathrm{pH}$ for which albumin, bicarbonate and ammonia in the lining fluid are responsible (Hunt et al., 2002) and [ID (Reininghaus, 1994)]. This multiple buffering system prevents tobacco smoke, including the ammonia in the smoke, to alter the $\mathrm{pH}$ at the luminal side of the airways (Hoffmann and Hoffmann, 1998).

As mentioned before, treatment of cigarettes with ammonium compounds increases the amount of free-base nicotine presented to the airways, i.e., relatively more nicotine is 'deposited' as free-base nicotine in the lining fluid of the respiratory tract. However, considering the $\mathrm{pH}$-value of the lining fluid $(\mathrm{pH}$ of 7.6), about half of the free-base nicotine will be protonated again, leaving the remaining non-protonated nicotine available for rapid absorption.

To our surprise, no studies from independent researchers could be retrieved that described the effect of tobacco ammoniation on blood nicotine level. As quoted before, one study, sponsored by the tobacco industry, showed that treatment of tobacco with urea or DAP failed to increase the blood nicotine level (Armitage et al., 2004).

In this respect it is remarkable that similar amounts of nicotine are absorbed from (generally) acidic cigarette smoke as compared to alkaline cigar smoke [ID (Reininghaus, 1994)]; see also (Armitage et al., 1968). Considering the differences in smoking techniques of cigarette and cigar smokers, like the usually superficial (less deep) inhalation by cigar smokers, this similarity in nicotine delivery may also be attributed to a higher absorption of nicotine from cigars by the mucous layer in the mouth.

\section{Discussion}

The present review shows that the exposure of cigarette smokers to free-base nicotine can be easily increased by adding ammonia to whole tobacco. It is concluded, that ammonia increases the bioavailability of nicotine via multiple mechanisms that are based on the fundamental property of weak bases to be deprotonated at high alkalinity: (1) liberation of nicotine from whole tobacco; (2) increase of the vapor-solid particle ratio of nicotine; (3) ammonia top affects the proportion of the free base in smoke that is more readily absorbed.

Ammonia and certain ammonium salts increase the $\mathrm{pH}$ value of tobacco, so that a larger portion of the weak base alkaloid nicotine will acquire the free-base form. In contrast to protonated nicotine that is confined to its cellular structure, freebase nicotine easily passes cellular membranes and is a volatile entity. Consequently ammonia liberates nicotine from the cellular structures of the tobacco leaf, and upon heating free-base nicotine diffuses to the vapor phase. As such, it is clear that ammoniation of tobacco increases the dose of nicotine (i.e., concentration of free-base nicotine in smoke), the smoker will be exposed to.

One may, however, question whether ammonia also facilitates the pulmonary absorption per se (rate of absorption and total amount of nicotine absorbed) (Sloan and Morie, 1976). Considering the high buffer capacity of the lining fluid, it 
is unlikely that ammonia affects the $\mathrm{pH}$ at the luminal side of the bronchioli (CDC, 1988, Hunt et al., 2000, Hunt et al., 2002 and Kostikas et al., 2002). Therefore, the enhancing effect of ammonia on nicotine absorption will finally be confined to a concentration-driven increase in absorption due to an elevation of the free-base nicotine concentration in MS smoke.

Henningfield et al. (Henningfield et al., 2004) recently proposed that ammonium compounds may increase the reinforcing potency of cigarettes via: (i) enrichment of the MS smoke with nicotine; (ii) a better and faster absorption of nicotine; (iii) a higher impact of nicotine at peripheral and central nicotine receptors; and (iv) improvement of the sensory characteristics (Henningfield et al., 2004). Though their proposal largely conforms to our conclusion, no corroborative data on the higher impact at nicotine receptors, and the improvement of the sensory characteristics have been described by independent investigators. To our surprise and despite the large research efforts (see below), no conclusive data on the enhancement of nicotine plasma levels (bioavailability) by cigarette ammoniation could be retrieved.

Clearly, the tobacco industry is interested in the development of cigarettes that give a rapid and high delivery of nicotine (Bates et al., 1999). Several tobacco companies use variations of "ammonia technology", originally described in the late 1960 s by Philip Morris (Marlboro), with the aim to manipulate nicotine delivery to the smoker (Kessler et al., 1996); see also [ID (B\&W, 1990a)]. The dramatic increase in PM's sales since, may well be due to this innovative ammonia technology (Bates et al., 1999 and Hurt and Robertson, 1998); see also [ID (Wayne et al., 2003)]. Until the late 1980s (Hurt and Robertson, 1998, Muggli et al., 2004 and USDHHS, 1988), this phenomenon of ammoniation (also known as 'nicotine free-basing'), was publicly not known, implicating that the tobacco consumer was intentionally diverted by the tobacco companies that applied the ammonia technology. The nicotine values depicted on cigarette packages (ranging from 0.9 to about $1.1 \mathrm{mg}$ ) reflect the values of "tar"-bound nicotine that is obtained via measurements according to the FTC-guidelines. These nicotine values under-estimate the factual exposure during cigarette smoking, since the volatile nicotine fraction in the smoke of these cigarettes is not considered. As a result, the nicotine value described on the package gives no reliable information with respect to the true dose the consumer will be exposed to. In 2001, Philip Morris decided to stop adding ammonia to its cigarettes sold in the EU, but not to those marketed in the USA.

In addition to the higher exposure of smokers to ammonia (and nicotine), it should be mentioned that the addition of ammonia to tobacco increases indoor (and outdoor) ambient air pollution. Ammonia in SS smoke with 40-170 fold higher levels than in MS smoke is mainly responsible for the ammonia in environmental tobacco smoke (ETS). Still, the indoor air level of $10 \mu \mathrm{g}$ of ammonia per $\mathrm{m}^{3}$ that will be reached as a result of smoking one cigarette (releasing some $5000 \mu \mathrm{g}$ of ammonia) in a small room of $500 \mathrm{~m}^{3}$ remains far below the PEL/STEL value of $18-27 \mathrm{mg} / \mathrm{m}^{3}$. On the other hand, certain people with hypersensitive airways may show throat irritation and COPD-like symptoms at such low ammonia concentrations. Secondly, smokers- and less so nonsmokers- are acutely exposed to relatively high levels of ammonia (up to $750 \mathrm{ppm}$ ), which are known cause throat irritation, or may even elicit chronic obstructive lung disease (Brautbar et al., 2003). Typical urban and non-urban ambient ammonia levels, to be mentioned here for comparison, are around 20 and $5 \mu \mathrm{g} / \mathrm{m}^{3}$ (30 and $7 \mathrm{ppb}$ ), respectively. The daily intake of $0.1-0.5 \mathrm{mg}$ of ammonia by a non-smoker via ETS and $35 \mathrm{mg}$ of ammonia via MS by typical package-a-day smoker, is comparable to the $18 \mathrm{mg}$ of ammonia that is normally 
ingested per day, so that no systemic adverse health effects are to be anticipated.

The majority of the data referring to a promoting effect of ammonia on nicotine delivery is derived from tobacco internal documents, that have not been reviewed by independent scientists working in the public domain, and should, therefore, be considered with caution. To properly assess the rationale and the adverse effects of ammonia as tobacco additive it is recommended to perform independent public-accessible research to ammoniated tobacco products. Relevant research topics that should be addressed include the relation between the smoke and blood nicotine level, and between bioavailability (higher or prolonged exposure) and brain nicotine level.

\section{Acknowledgements}

This study was financially supported by the Dutch Ministry of Health, Welfare and Sports (VWS) and the Dutch Food and Consumer Product Safety Authority (VWA). No support was received from commercial tobacco companies or any other source. 


\section{References}

Anonymous, 1979 Anonymous, Subcommittee on ammonia and Committee of medical and biologic effects of environmental pollutants; Ammonia, University Park Press, International Publishers in Science and Medicine, Baltimore (USA) (1979).

Armitage and Turner, 1970 A.K. Armitage and D.M. Turner, Absorption of nicotine in cigarette and cigar smoke through the oral mucosa, Nature 226 (1970), pp. 1231-1232.

Armitage et al., 2004 A.K. Armitage, M. Dixon, B.E. Frost, D.C. Mariner and N.M. Sinclair, The effect of tobacco blend additives on the retention of nicotine and solanesol in the human respiratory tract and on subsequent plasma nicotine concentrations during cigarette smoking, Chemical Research in Toxicology 17 (2004), pp. 537-544.

Armitage et al., 1968 A.K. Armitage, G.H. Hall and C.F. Morrison, Pharmacological basis for the tobacco smoking habit, Nature 217 (1968), pp. 331-334.

B\&W, 1990a B\&W., 1990a. Ammonia technology. Internal document. PLA/cW/997/0747D (1/3/90).

B\&W, 1990b B\&W., 1990b. Ammoniation technology in tobacco products. Internal document. 566416046-566416063.

B\&W, 1991 B\&W., 1991. Root Technology-A Handbook for Leaf Blenders and Product Developers. Internal document (No. 8919).

Backhurst, 1966 Backhurst, J.D., 1966. Further work on "extractable" nicotine. Internal document. RD.437-R, pp. 650009837-650009905.

Baker, 1999 R.R. Baker, Smoke chemistry. In: D.L. Davis and M.T. Nielsen, Editors, Tobacco: Production, Chemistry and Technology, Coresta, Blackwell Science Ltd., London, UK (1999), pp. 398439.

Baker et al., 2004a R.R. Baker, E.D. Massey and G. Smith, An overview of the effects of tobacco ingredients on smoke chemistry and toxicity, Food and Chemical Toxicology 42 (2004) (Suppl.), pp. S53-S83.

Baker et al., 2004b R.R. Baker, d.S. Pereira Jr. and G. Smith, The effect of tobacco ingredients on smoke chemistry. Part II: casing ingredients, Food and Chemical Toxicology 42 (2004) (Suppl.), pp. S39-S52.

Bases, 1984 Il. Bases, The distribution of cigarette smoke components between mainstream and sidestream smoke, Beitrage zur Tabak-forschung International 12 (1984), pp. 199-209.

BAT, 1970 BAT., 1970. Use of ammonia/ammonium compounds/urea. Internal document.

BAT, 1982 BAT., 1982. Ammonia. Internal document. Washington Tobacco Litigation (400702976), pp. 043566-043572.

BAT, 1988 BAT., 1988. Forschung und entwicklung B.A.T. zigarettenfabrieken GmbH. Internal document. Germany (5394), pp. 402363924-402363962.

BAT, 1995 BAT., 1995. How does pH affect transfer of nicotine to smoke? Internal document, pp. 56630379-56630383.

Bates et al., 1999 Bates, C., Jarvis, M., Connolly, G., 1999. Tobacco additives: cigarette engineering and nicotine addiction. Available from: <www.ash.org.uk/html/regulation/html/additives.html>.

Benowitz and Henningfield, 1994a N.L. Benowitz and J.E. Henningfield, Establishing a nicotine threshold for addiction. The implications for tobacco regulation, New England Journal of Medicine 331 (1994), pp. 123-125.

Benowitz and Jacob, 1994b N.L. Benowitz and P. Jacob III, Metabolism of nicotine to cotinine studied by a dual stable isotope method, Clinical Pharmacology and Therapeutics 56 (1994), pp. 483-493. 
Benowitz et al., 1983 N.L. Benowitz, S.M. Hall, R.I. Herning, P. Jacob III, R.T. Jones and A.L. Osman, Smokers of low-yield cigarettes do not consume less nicotine, New England Journal of Medicine 309 (1983), pp. 139-142.

Boyle et al., 2004 P. Boyle et al., Tobacco: Science, Policy and Public Health (first ed.), Oxford University Press, Oxford (UK) (2004).

Brautbar et al., 2003 N. Brautbar, M.P. Wu and E.D. Richter, Chronic ammonia inhalation and interstitial pulmonary fibrosis: a case report and review of the literature, Archives of Environmental Health 58 (2003), pp. 592-596.

Burch et al., 1993 S.G. Burch, L.P. Gann, K.M. Olsen, P.J. Anderson, F.C. Hiller and M.L. Erbland, Effect of $\mathrm{pH}$ on nicotine absorption and side effects produced by aerosolized nicotine, Journal of Aerosol Medicine 6 (1993), pp. 45-52.

Carmines, 2002 E.L. Carmines, Evaluation of the potential effects of ingredients added to cigarettes. Part 1: cigarette design, testing approach, and review of results, Food and Chemical Toxicology $\mathbf{4 0}$ (2002), pp. 77-91.

CDC, 1974 CDC., 1974. NIOSH criteria documents criteria for a recommended standard: occupational exposure to ammonia DHHS (NIOSH) Publication No. 74-136. Available from: $<$ www.cdc.gov/Niosh/74-136.html>.

CDC, 1988 CDC., 1988. The health consequences of smoking: a report of the surgeon general. Available from: <www.cdc.gov/tobacco/sgr/sgr_2004/index.htm>.

Counts et al., 2004 M.E. Counts, F.S. Hsu, S.W. Laffoon, R.W. Dwyer and R.H. Cox, Mainstream smoke constituent yields and predicting relationships from a worldwide market sample of cigarette brands: ISO smoking conditions, Regulatory Toxicology and Pharmacology 39 (2004), pp. 111-134.

Covington and Burling, 1993 Covington, Burling, 1993. Summary of data on ammonium phosphate dibasic. Internal document, pp. 89233696-89233705.

Covington and Burling, 1994 Covington, Burling, 1994. Summary of data on ammonia/ammonium hydroxide. Internal document, pp. 2051516668-2051516679.

Creighton, 1987 Creighton, D.E. et al., 1987. The significance of pH in tobacco and tobacco smoke. Internal document. BATCO Confidential-Category II: Minnesota Tobacco Litigation (Trial Exhibit $11,984)$.

Cummings et al., 2002 K.M. Cummings, C.P. Morley and A. Hyland, Failed promises of the cigarette industry and its effect on consumer misperceptions about the health risks of smoking, Tobacco Control 11 (2002) (Suppl. 1), pp. I110-I117.

Davis and Nielsen, 1999 D.L. Davis and M.T. Nielsen, Tobacco: Production, Chemistry and Technology, Blackwell Science, Oxford, UK (1999).

Diethelm et al., 2004 Diethelm, P., Rielle, J.-C., Ms Kee, M., 2004. The whole truth and nothing but the truth? The research that Philip Morris did not want to see. Available from:

$<$ www.imgae.thelancet.com/extras/03art7306web.pdf $>$.

Dixon and Lambing, 2000 M. Dixon and K.S.J.I. Lambing, On the transfer of nicotine form tobacco to

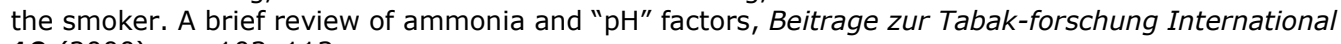
19 (2000), pp. 103-113.

Djordjevic, 2004 M.V. Djordjevic, Nicotine dosing characteristics across tobacco products. In: P. Boyle, N. ray, J. Henningfield, J. Sefrin and W. Zatonski, Editors, Tobacco: Science, Policy and Public Health, Oxford University Press, Oxford (UK) (2004), pp. 181-204.

Djordjevic et al., 2000 M.V. Djordjevic, S.D. Stellman and E. Zang, Doses of nicotine and lung carcinogens delivered to cigarette smokers, Journal of the National Cancer Institute 92 (2000), pp. $106-111$. 
Domino, 1999 E.F. Domino, Pharmacological significance of nicotine. In: J.W. Gorrod and P. Jacob III, Editors, Analytical Determination of Nicotine and Related Compounds and Their Metabolites (first ed.), Elsevier Science B.V., Amsterdam, The Netherlands (1999), pp. 1-12.

Domino et al., 2004 E.F. Domino, L. Ni, Y. Xu, R.A. Koeppe, S. Guthrie and J.K. Zubieta, Regional cerebral blood flow and plasma nicotine after smoking tobacco cigarettes, Progress in NeuroPsychopharmacology and Biological Psychiatry 28 (2004), pp. 319-327.

Drope and Chapman, $2001 \mathrm{~J}$. Drope and S. Chapman, Tobacco industry efforts at discrediting scientific knowledge of environmental tobacco smoke: a review of internal industry documents, Journal of Epidemiology and Community Health 55 (2001), pp. 588-594.

EPA-FTC, 1978 EPA-FTC., 1978. Environmental Protection Agency and Federal Trade commission. Cigarette Smoke, pp. 80419204-80419345.

Ezzati and Lopez, 2003 M. Ezzati and A.D. Lopez, Measuring the accumulated hazards of smoking: global and regional estimates for 2000, Tobacco Control 12 (2003), pp. 79-85.

Guthrie et al., 2004 S.K. Guthrie, L. Ni, J.K. Zubieta, C.J. Teter and E.F. Domino, Changes in craving for a cigarette and arterial nicotine plasma concentrations in abstinent smokers, Progress in NeuroPsychopharmacology and Biological Psychiatry 28 (2004), pp. 617-623.

Hebert, 2004 E.R. Hebert, What's new in nicotine \& tobacco research?, Nicotine Tobacco Research 6 (2004), pp. 191-198.

Heck, 1993 Heck, J.D., 1993. Summary of data on ammonia/ammonium hydroxide. Internal document. Available from: <www.tobaccodocuments.org/lor/89233679-3695.html>, pp. 8923367989233695.

Henningfield, 1995 J.E. Henningfield, Nicotine medications for smoking cessation, New England Journal of Medicine 333 (1995), pp. 1196-1203.

Henningfield and Benowitz, 2004 J. Henningfield and N.L. Benowitz, Pharamcology of nicotine addiction. In: P. Boyle, N. Gray, J. Henningfield, J. Sefrin and W. Zatonski, Editors, Tobacco: Science, Policy and Public Health (first ed.), Oxford, University Press, Oxford (UK) (2004), pp. 129-147.

Henningfield et al., 2004 J. Henningfield, J. Pankow and B. Garrett, Ammonia and other chemical base tobacco additives and cigarette nicotine delivery: issues and research needs, Nicotine Tobacco Research 6 (2004), pp. 199-205.

Henningfield et al., 1993 J.E. Henningfield, J.M. Stapleton, N.L. Benowitz, R.F. Grayson and E.D. London, Higher levels of nicotine in arterial than in venous blood after cigarette smoking, Drug and Alcohol Dependence 33 (1993), pp. 23-29.

Hoffmann and Hoffmann, 1997 D. Hoffmann and I. Hoffmann, The changing cigarette, 1950-1995, Journal of Toxicology and Environmental Health 50 (1997), pp. 307-364.

Hoffmann and Hoffmann, 1998 D. Hoffmann and I. Hoffmann, Chemistry and Toxicology. In: D.R. Shopland and D.M. Burns, Editors, Monograph 9: Cigars: Health Effects and Trends, US Department of Health and Human services, National Institutes of Health, National Cancer Institute, Bethesda (1998), pp. 55-104.

Hoffmann and Hoffmann, 2004 I. Hoffmann and D. Hoffmann, The changing cigarette: chemical studies and bioassays. In: P. Boyle, N. Gray, J. Henningfield, J. Sefrin and W. Zatonski, Editors, Tobacco: Science, Policy and Public Health, Oxford University Press, Oxford (UK) (2004), pp. 53-92.

Huang et al., 2003 C.B. Huang, R. Bassfield, B. Dabney and F. Hsu, Determination of total ammonia in mainstream smoke, Beitrage zur Tabak-forschung International 20 (2003), pp. 389-393.

Hunt et al., 2002 J.F. Hunt, E. Erwin, L. Palmer, J. Vaughan, N. Malhotra, T.A. Platts- Mills and B. Gaston, Expression and activity of pH-regulatory glutaminase in the human airway epithelium, American Journal of Respiratory and Critical Care Medicine 165 (2002), pp. 101-107. 
Hunt et al., 2000 J.F. Hunt, K. Fang, R. Malik, A. Snyder, N. Malhotra, T.A. Platts- Mills and B. Gaston, Endogenous airway acidification. Implications for asthma pathophysiology, American Journal of Respiratory and Critical Care Medicine 161 (2000), pp. 694-699.

Hurt and Robertson, 1998 R.D. Hurt and C.R. Robertson, Prying open the door to the tobacco industry's secrets about nicotine, Journal of the American Medical Association 280 (1998), pp. 11731181.

Issley et al., 2004 Issley, S., Lang, E., Hooker, E., 2004. Toxicity, Ammonia. Available from: $<$ www.emedicine.com/emerg/topic846.htm>.

Iwase et al., 1991 A. Iwase, M. Aiba and S. Kira, Respiratory nicotine absorption in non-smoking females during passive smoking, International Archives of Occupational and Environmental Health 63 (1991), pp. 139-143.

Johnson, 1977 Johnson, R.R., 1977. Effects of light ammonia treatment on cigarette smoke properties. Internal document. Bates GF-008-77x, pp. 650353785-650353803.

Johnson, 1989 Johnson, R., 1989. Ammonia technology conference minutes. Available from: <www.tobaccodocuments.org/product_design/1097876.snapshot_bw.0001097876>,pp. 1-148.

Karan and Benowitz, 2000 L.D. Karan and N.L. Benowitz, Substance abuse: dependency and treatment. In: S.G. Carruthers, B.B. Hoffman, K.L. Melmon and D.W. Nierenberg, Editors, Clinical Pharmacology (fourth ed.), MsGraw-Hill: Edical Publishing Division, New York (USA) (2000), pp. 1053-1089.

Kessler, 1994a Kessler, D.A., 1994a. Kessler's statement concerning the impact of ammoniacontaining (or pH-changing) compounds on nicotine delivery, p. 2024555757.

Kessler, 1994b D.A. Kessler, The control and manipulation of nicotine in cigarettes, Tobacco Control 3 (1994), pp. 362-369.

Kessler and Myers, 2001 D.A. Kessler and M.L. Myers, Beyond the tobacco settlement, New England Journal of Medicine 345 (2001), pp. 535-537.

Kessler et al., 1996 D.A. Kessler, A.M. Witt, P.S. Barnett, M.R. Zeller, S.L. Natanblut, J.P. Wilkenfeld, C.C. Lorraine, L.J. Thompson and W.B. Schultz, The Food and Drug Administration's regulation of tobacco products, New England Journal of Medicine 335 (1996), pp. 988-994.

Kostikas et al., 2002 K. Kostikas, G. Papatheodorou, K. Ganas, K. Psathakis, P. Panagou and S. Loukides, $\mathrm{pH}$ in expired breath condensate of patients with inflammatory airway diseases, American Journal of Respiratory and Critical Care Medicine 165 (2002), pp. 1364-1370.

Larson, 1980 Larson, T.M., 1980. Nicotine transfer process, Patent 951,071.

Lauterbach, $2000 \mathrm{J.H}$. Lauterbach, A critical assessment of recent work on the application of gas/particle partitioning theories to cigarette smoke, Beitrage zur Tabak-forschung International 19 (2000), pp. 65-83.

Lee et al., 2004 E.M. Lee, J.L. Malson, E.T. Moolchan and W.B. Pickworth, Quantitative comparisons between a nicotine delivery device (Eclipse) and conventional cigarette smoking, Nicotine Tobacco Research 6 (2004), pp. 95-102.

Leffingwell, 1999 J.C. Leffingwell, Leaf Chemistry: basic chemical constituents of tobacco leaf and differences among tobacco types. In: D.L. Davis and M.T. Nielsen, Editors, Tobacco: Production, Chemistry and Technology, Coresta, Blackwell Science Ltd., London, UK (1999), pp. 265-284.

Lorillard, 1984 Lorillard., 1984. Report on the nicotine and impact improvement (project, B-412, for 1983). Internal document. Lorillard Research Center Greensboro.

Lunell et al., 2000 E. Lunell, L. Molander, K. Ekberg and J. Wahren, Site of nicotine absorption from a vapour inhaler-comparison with cigarette smoking, European Journal of Clinical Pharmacology $\mathbf{5 5}$ (2000), pp. 737-741. 
Malson et al., 2003 J.L. Malson, E.M. Lee, R. Murty, E.T. Moolchan and W.B. Pickworth, Clove cigarette smoking: biochemical, physiological, and subjective effects, Pharmacology, Biochemistry and Behavior 74 (2003), pp. 739-745.

McGehee et al., 1995 D.S. McGehee, M.J. Heath, S. Gelber, P. Devay and L.W. Role, Nicotine enhancement of fast excitatory synaptic transmission in CNS by presynaptic receptors, Science 269 (1995), pp. 1692-1696.

Molander and Lunell, $2001 \mathrm{~L}$. Molander and E. Lunell, Pharmacokinetic investigation of a nicotine sublingual tablet, European Journal of Clinical Pharmacology 56 (2001), pp. 813-819.

Muggli et al., 2004 M.E. Muggli, E.M. Le Gresley and R.D. Hurt, Big tobacco is watching: British American Tobacco's surveillance and information concealment at the Guildford depository, Lancet 363 (2004), pp. 1812-1819.

Neurath, 1969 v.G. Neurath, Stickstoffverbindungen des tabakrauches, Beitrage zur Tabak-forschung International 5 (1969), pp. 115-133.

Pankow, 2001 J.F. Pankow, A consideration of the role of gas/particle partitioning in the deposition of nicotine and other tobacco smoke compounds in the respiratory tract, Chemical Research in Toxicology 14 (2001), pp. 1465-1481.

Pankow et al., 1997 J.F. Pankow, B.T. Mader, L.M. Isabelle, W. Luo, A. Pavlick and C. Liang, Conversion of nicotine in tobacco smoke to its volatile and available free-base form through the action of gaseous ammonia, Environmental Science and Technology 33 (1997), p. 1320.

Peedin, 1999 G.F. Peedin, Production Practices. In: D.L. Davis and M.T. Nielsen, Editors, Tobacco: Production, Chemistry and Technology, Coresta, Blackwell Science Ltd., Oxford (UK) (1999), pp. 104142

Pich et al., 1997 E.M. Pich, S.R. Pagliusi, M. Tessari, D. Talabot-Ayer, v.H. Hooft and C. Chiamulera, Common neural substrates for the addictive properties of nicotine and cocaine, Science 275 (1997), pp. 83-86.

Reininghaus, 1994 Reininghaus, W., 1994. Bioavailability of Nicotine. Internal document. Bates No: 2050878704.

Rodgman, 2000 A. Rodgman, Smoke pH: a review, Beitrage zur Tabak-forschung International 19 (2000), pp. 117-139.

Schroeder, 2004 S.A. Schroeder, Tobacco control in the wake of the 1998 master settlement agreement, New England Journal of Medicine 350 (2004), pp. 293-301.

Seeman et al., 1999 J.I. Seeman, J.A. Fournier, J.B. Paine III and B.E. Waymack, The form of nicotine in tobacco. Thermal transfer of nicotine and nicotine acid salts to nicotine in the gas phase, Journal of Agricultural and Food Chemistry 47 (1999), pp. 5133-5145.

Seeman et al., 2004 J.I. Seeman, P.J. Lipowicz, J.J. Piade, L. Poget, E.B. Sanders, J.P. Snyder and C.G. Trowbridge, On the deposition of volatiles and semivolatiles from cigarette smoke aerosols: relative rates of transfer of nicotine and ammonia from particles to the gas phase, Chemical Research in Toxicology 17 (2004), pp. 1020-1037.

Silverman et al., 1949 L. Silverman, J.L. Whittenberger and J. Muller, Physiological response of man to ammonia in low concentrations, Journal of Industrial Hygiene Toxicology 31 (1949), pp. 74-78.

Sloan and Morie, 1974 C.H. Sloan and G.P. Morie, Determination of ammonia in tobacco and tobacco smoke with an ammonia electrode, Analytica Chimica Acta 69 (1974), pp. 243-247.

Sloan and Morie, 1976 C.H. Sloan and G.P. Morie, Determination of unprotonated ammonia in whole cigarette smoke, Beitrage zur Tabak-forschung International 8 (1976), pp. 362-365.

Smith et al., 2001 C.J. Smith, T.A. Perfetti, M.A. Rumple, A. Rodgman and D.J. Doolittle, "IARC Group 2B carcinogens" reported in cigarette mainstream smoke, Food and Chemical Toxicology 39 (2001), pp. 183-205. 
Soc. Neurosc., 2004 Soc. Neurosc., 2004. Society of Neurosciences. Brain facts: a primer on the brain and nervous system. Available from: <www.web.sfn.org/content/Publications/BrainFacts/index.html>.

Spanel et al., 1998 P. Spanel, S. Davies and D. Smith, Quantification of ammonia in human breath by the selected ion flow tube analytical method using $\mathrm{H}_{3} \mathrm{O}^{+}$and $\mathrm{O}_{2}^{+}$precursor ions, Rapid Communications in Mass Spectrometry 12 (1998), pp. 763-766.

Stabbert et al., 2003 R. Stabbert, P. Voncken, K. Rustemeier, H.J. Haussmann, E. Roemer, H. Schaffernicht and G. Patskan, Toxicological evaluation of an electrically heated cigarette. Part 2: Chemical composition of mainstream smoke, Journal of Applied Toxicology 23 (2003), pp. 329-339.

Steele et al., 1994 Steele, R., Hayes, J.R., Appleton, S., 1994. A review of the literature pertaining to the toxicology of ammonia. Internal document. R010228, pp. 51463 1729-514631747.

Sudholt, 1996 Sudholt, M.A., 1996. Summary of the effects of ammonia carbonate, ammonium bicarbonate, urea and diammonium phosphate on smoke $\mathrm{pH}$, smoke data and leaf chemistry. Internal document. Q449-Analytical support- Bates No. 89291533, pp. 89291533-89291545.

USDHHS, 1988 USDHHS., 1988. The health consequences of smoking: nicotine addition; a report of the Surgeon General. Available from: <www.cdc.gov/tobacco/sgr_1988/index.htm>.

USDHHS, 1990 USDHHS., 1990. Toxicological profile for ammonia (TP-90-03). Public Health Service, Agency for Toxic Substances and Disease Registration.

Van Andel et al., 2003 Van Andel, I., Rambali, B., van Amsterdam, J.G.C., Wolterink, G., van Aerts, L.A.G.J.M., Vleeming, W., 2003. Nicotine addiction. RIVM Report 650270004/2003.

Wayne et al., 2003 Wayne, G.F., Pankow, J.F., Connolly, G.N., Henningfield, J.E., 2003. Brand differences of free-base nicotine delivery in cigarette smoke: the view of the tobacco industry documents.

Weast, 1970 R.C. Weast, CRC Handbook of Chemistry and Physics (51th ed.), CRC Press (1970) D160.

WHO, 1986 WHO., 1986. Ammonia: Environmental Health Criteria 54. Available from: <www.inchem.org/documents/ehc/ehc/ehc54.htm>.

WHO, 2004 WHO., 2004. Ammonium Carbonate and ammonium hydrogen carbonate (Ammonium salts).

WHO-TFI, 2004 WHO-TFI., 2004. WHO: Why is tobacco a public health priority? Available from: $<$ www.who.int/tobacco/health_priority/en/>.

Wilner and Feingold, 2000 Wilner, N.S., Feingold, A., 2000. The scientific basis for tobacco industry liability. Available from: <www.spohrer.com/scientific.pdf>. 